폐전기차 셀분말의 열처리 조건에 따른 선택적 리튬침출 연구

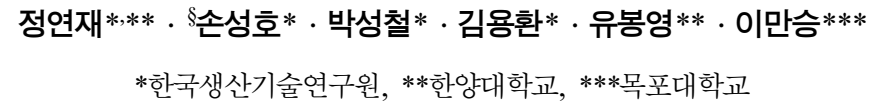

\title{
Study on Selective Lithium Leaching Effect on Roasting Conditions of the Waste Electric Vehicle Cell Powder
}

\author{
Yeon Jae Jung***, ${ }^{\S}$ Seong Ho Son*, Sung Cheol Park*, Yong Hwan Kim*, \\ Bong Young Yoo** and Man Seung Lee*** \\ *Korea Institute of Industrial Technology, Incheon 21999, Korea \\ **Department of Materials Science and Chemical Engineering, Hanyang University, Ansan 15588, korea \\ ***Department of Advanced Materials Science \& Engineering, Institute of Rare Metal, \\ Mokpo National University, Mokpo 58554, Korea
}

\begin{abstract}
요 약
최근, 전기차 증가에 따른 리튬 전지의 사용량 증가로 리튬 가격 증가 및 폐리튬전지 발생량이 증가하고 있다. 이러한 이유로 폐 리튬전지 내 리튬 회수에 대한 연구가 진행되고있다 ${ }^{1)}$. 본 연구에서는 폐전기차 셀분말의 열처리 조건에 따른 선택적 리튬 침출에 관한 연구를 진행하였다. 셀 분말 $\left(\mathrm{LiNi}_{\mathrm{x}} \mathrm{Co}_{\mathrm{y}} \mathrm{Mn}_{\mathrm{z}} \mathrm{O}_{2}, \mathrm{LiCoO}_{2}\right)$ 로부터 선택적 리튬 침출을 위해서는 환원을 통한 상변화 및 분리가 필 요하다. 폐전기차 셀분말 내 탄소는 고온에서 산소와 반응하여 환원제 역할을 한다. 적정 온도를 알고자 대기/질소 분위기에서 TG$\mathrm{DSC}$ 분석 및 $550 \sim 850{ }^{\circ} \mathrm{C}$ 열처리 후, XRD 분석을 하였다. 열처리 된 분말은 $\mathrm{ICP}$ 분석을 위해 D.I water에서 1:10 비율로 침 출 후 분석하였다. $\mathrm{XRD}$ 분석결과, $700{ }^{\circ} \mathrm{C}$ 에서 $\mathrm{Li}_{2} \mathrm{CO}_{3}$ 피크가 확인되었다. $850{ }^{\circ} \mathrm{C}$ 열처리 시 $\mathrm{Li}_{2} \mathrm{O}$ 의 피크가 확인되었는데, 이는 $\mathrm{Li}_{2} \mathrm{CO}_{3}$ 가 $723{ }^{\circ} \mathrm{C}$ 이상의 온도에서 $\mathrm{Li}_{2} \mathrm{O}$ 와 $\mathrm{CO}_{2}$ 로 분해되었기 때문이다. 또한 $\mathrm{Li}_{2} \mathrm{O}$ 와 $\mathrm{Al}_{2} \mathrm{O}_{3}$ 와 반응으로 $\mathrm{LiAlO}_{2}$ 가 확인되었다. 850 ${ }^{\circ} \mathrm{C}$ 에서 열처리 시 $\mathrm{Li}$ 침출율이 낮아졌는데 이는 $\mathrm{LiAlO}_{2}$ 가 D.I water에서 침출하지 않기 때문으로 판단된다. 리튬 침출율의 경우 열 처리의 조건에 따라 달라지며, 질소 분위기 중 $700{ }^{\circ} \mathrm{C}$ 로 열처리 시 약 $45 \%$ 의 리튬침출이 확인되었다. 침출 용액을 고-액분리 후 증발농축하여 XRD 분석을 실시한 결과, $\mathrm{Li}_{2} \mathrm{CO}_{3}$ 의 피크를 확인하였다.
\end{abstract}

주제어 : 폐전기차 셀 분말, 재활용, 선택적 리튬침출, 열처리

\begin{abstract}
Recently, the use of lithium ion battery(LIB) has increased. As a result, the price of lithium and the amount spent lithium on ion battery has increased. For this reason, research on recycling lithium in waste LIBs has been conducted ${ }^{1}$. In this study, the effect of roasting for the selective lithium leaching from the spent LIBs is studied. Chemical transformation is required for selective lithium leaching in $\mathrm{NCM} \mathrm{LiNi}_{\mathrm{x}} \mathrm{Co}_{\mathrm{y}} \mathrm{Mn}_{\mathrm{z}} \mathrm{O}_{2}$ ) of the spent LIBs. The carbon in the waste EV cell powder reacts with the oxygen of the oxide at high temperature. After roasting at $550 \sim 850{ }^{\circ} \mathrm{C}$ in the Air $/ \mathrm{N}_{2}$ atmosphere, the chemical transformation is analysed by XRD. The heat treated powders are leached at a ratio of 1:10 in D.I water for ICP analysis. As a result of XRD analysis, $\mathrm{Li}_{2} \mathrm{CO}_{3}$ peak is observed at $700{ }^{\circ} \mathrm{C}$. After the heat treatment at $850{ }^{\circ} \mathrm{C}$, a peak of $\mathrm{Li}_{2} \mathrm{O}$ was confirmed because $\mathrm{Li}_{2} \mathrm{CO}_{3}$

\footnotetext{
- Received : November 1, 2019 · Revised : November 19, 2019 · Accepted : November 25, 2019

$\S$ Corresponding Author : Seong Ho Son (E-mail : shson@kitech.re.kr)

Surface R \& D Group, Korea Institute of Industrial Technology, 156 Gaetbeol-ro, Yeonsu-gu, Incheon 21999, Korea

(c) The Korean Institute of Resources Recycling. All rights reserved. This is an open-access article distributed under the terms of the Creative Commons Attribution Non-Commercial License (http://creativecommons.org/licenses/by-nc/3.0/), which permits unrestricted non-commercial use, distribution and reproduction in any medium, provided the original work is properly cited.
} 
is decomposed into $\mathrm{Li}_{2} \mathrm{O}$ and $\mathrm{CO}_{2}$ over $723{ }^{\circ} \mathrm{C}$. The produced $\mathrm{Li}_{2} \mathrm{O}$ reacted with $\mathrm{Al}$ at high temperature to form $\mathrm{LiAlO}_{2}$, which does not leach in D.I water, leading to a decrease in lithium leaching ratio. As a result of lithium leaching in water after heat treatment, lithium leaching ratio was the highest after heat treatment at $700{ }^{\circ} \mathrm{C}$. After the solid-liquid separation, over $45 \%$ of lithium leaching was confirmed by ICP analysis. After evaporation of the leached solution, peak of $\mathrm{Li}_{2} \mathrm{CO}_{3}$ was detected by XRD.

Key words : Waste electric vehicle cell powder, Recycling, Selective lithium leaching, Roasting

\section{1. 서 론}

International Energy Agency(IEA)는 전기차 재고는 매년 빠르게 증가할 것이며 그중 유럽, 미국, 중국이 주 를 이룰 것으로 예측하고 있다. 우리나라를 포함하여 세 계적으로 전기차 관련 정책과 Total Cost of Ownership (TCO) 절감은 전기차 시장의 규모를 크게 증가 시키고 있고 2030년까지 계속 될 것으로 예상된다. 시장 규모 가 커짐에 따라 도로 상의 전기차의 수는 2030년에는 2 억 2천만대에 이를 것으로 예측되고 있다2,3). 전기차의 시장규모 증가에 따라 전기차에서 발생하는 폐 배터리 처리 및 재소재화에 관한 연구는 필수적이라 할 수 있다.

전기차의 경우 높은 에너지 밀도와 저 중량의 특성을 지닌 $\mathrm{LIB}$ (Lithium ion secondary battery)가 주로 사 용되고 있다. 이러한 특성으로 LIB 생산량이 증가하고 있으며, 이에 따라 수명을 다한 배터리 처리 및 재활용 에 대한 연구가 진행 중이다 ${ }^{4,5)}$.

배터리 재활용을 위한 소재화 기술은 물질 부족이나 가격 상승을 완화할 수 있으며, 주요 재료의 비용 절감 으로 이어진다. 재활용 기술은 양극 재료 $(\mathrm{NCM})$ 의 비용 을 $25 \$ / \mathrm{kg}$ 에서 $10 \$ / \mathrm{kg}$ 으로 줄일 수 있다. $\mathrm{LIB}$ 는 종 류에 따라 차이는 있지만 보통 $4 \sim 7 \%$ 정도의 리튬 이 포함되어 있다. LIB내에 코발트 $(\mathrm{Co})$, 니켈 $(\mathrm{Ni})$, 망간
$(\mathrm{Mn})$ 의 경우 재활용이 활발하게 이루어 졌으나, 리튬 (Li)의 경우 경제적인 이유로 회수하지 않았다. 하지만 최근 리튬 가격의 상승에 따라 리튬회수에 대한 연구가 활발하게 진행 중이다-8).

따라서 본 연구에서는 폐전기차 셀 내에 리튬의 효율 적인 재활용을 위하여 셀 분말의 선택적 리튬 우선침출 을 할 수 있는 공정과 리튬의 회수율을 최대로 할 수 있는 열처리 및 침출 조건을 연구하였으며, 대략적인 내 용을 Fig. 1에 나타내었다. 기존 공정의 경우 Black powder로부터 리튬 회수 시 타 유가금속(코발트, 니켈, 망간 등)을 회수 한 이후 리틈을 추출하기 때문에 불순 물의 포함이 다량 된다. 하지만 선택적 리튬 침출 공정 적용 시 리튬을 선침출한다. 이후 고액 분리 후 산침출 을 함으로서 리튬회수 효율성을 높이고, 불순물이 적은 리튬화합물로 회수가 가능하다는 장점이 있다. 본 연구 에서는 열처리 및 침출 조건을 조절함으로써 리튬침출 율을 최적화하고, 타 유가금속과 분리하고자 하였다.

\section{2. 실험방법}

본 연구에서는 선택적 리튬침출을 위한 열처리 분위 기, 온도 및 시간 영향 평가를 통해 최적의 열처리 조 건을 선정하고, 침출 조건에 따른 침출율 분석을 통해

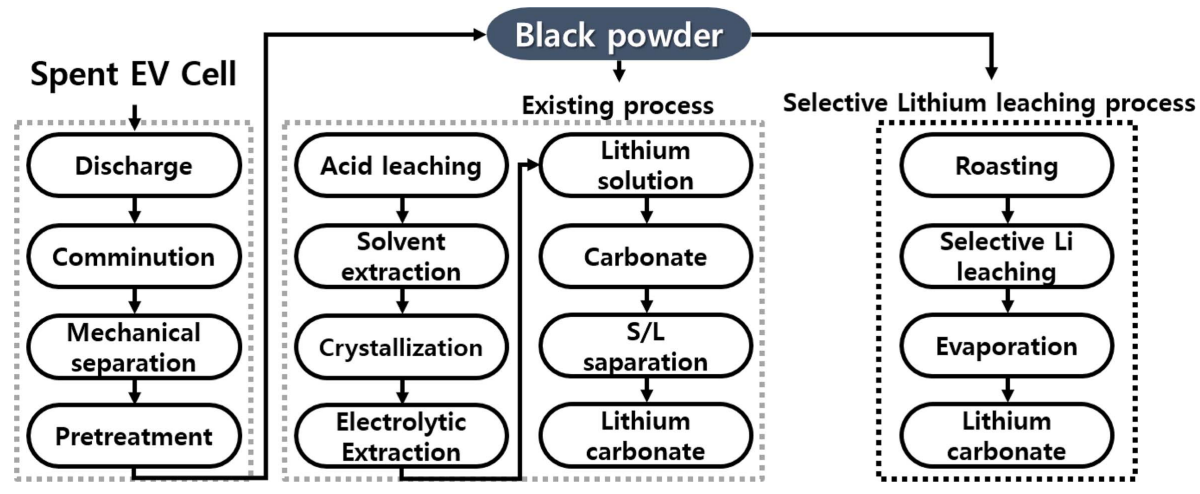

Fig. 1. Schematic diagram of existing process and selective lithium leaching process. 
Table 1. EV cell powder ICP analysis result

\begin{tabular}{|c|c|c|c|c|c|c|c|}
\hline Element & $\mathrm{Ni}$ & $\mathrm{Co}$ & $\mathrm{Mn}$ & $\mathrm{Li}$ & $\mathrm{Al}$ & $\mathrm{Cu}$ & $\mathrm{Fe}$ \\
\hline $\begin{array}{c}\text { Concentration } \\
\text { (Wt. \%) }\end{array}$ & 15.63 & 8.37 & 7.64 & 3.92 & 3.20 & 1.15 & 0.38 \\
\hline
\end{tabular}

리튬침출을 비교평가하였다. 실험에 사용된 Black powder는 국내 배터리 재활용 업체로부터 물리화학적 으로 분리 후 파쇄 및 분쇄되어진 분말을 사용하였다. 왕수(aqua regia)에서 파분쇄되어진 분말을 침출 하여 $\mathrm{ICP}$ 분석 분말의 금속양을 분석하였으며, 선택적 리튬침 출을 위한 열처리를 후 D.I water에서 침출을 통해 폐 전기차 셀 분말 내 리튬 중 침출된 리튬의 양으로 리 튬침출율을 계산하였다.

\section{1. (시료) 분석}

폐전기차 셀 분말은 특성상 포함하는 금속의 함량이 다르다. 따라서 ICP-OES (Inductively Coupled Plasma Optical Emission Spectrometer, Integra XL, GBC Scientific) 분석을 실시하였고, 성분 함량을 위해 셀에 포함되는 원소를 ICP로 분석을 실시한 결과 Table 1에 나타낸 것과 같이 리튬 $(\mathrm{Li})$ 외에 코발트 $(\mathrm{Co})$, 니켈 $(\mathrm{Ni})$, 망간 $(\mathrm{Mn})$ 등의 금속 함량을 정량적으로 알 수 있었다. 열처리 전 분말의 상을 확인을 위해 $\mathrm{XRD}(\mathrm{X}$-ray Diffraction, X'Pert-pro MPD,PANalytical)로 분석결과 Fig. 2에 나타난 것과 같이 $\mathrm{NCM}, \mathrm{LCO}$ 등의 리튬을 포함하는 산화물 및 탄소로 분석되었다. 탄소의 경우 전 기차 셀 분말에 약 $35 \%$ 로 알려져 있다 ${ }^{9)}$. 열처리 온 도를 알기 위하여 질소 및 대기 분위기에서 $\mathrm{TGA}$ 분석 을 한 결과 Fig. 3 에 나타난 것처럼 $400{ }^{\circ} \mathrm{C}$ 아래의 온 도에서 수분 및 유기물이 제거되며 $437^{\circ} \mathrm{C}$ 이상에서 탄

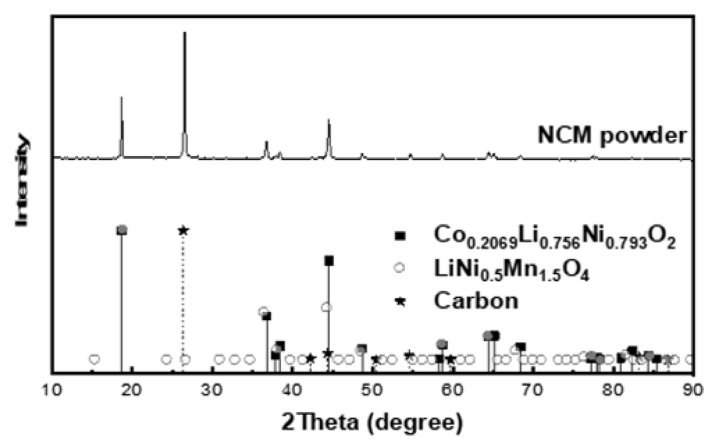

Fig. 2. EV cell powder XRD analysis.

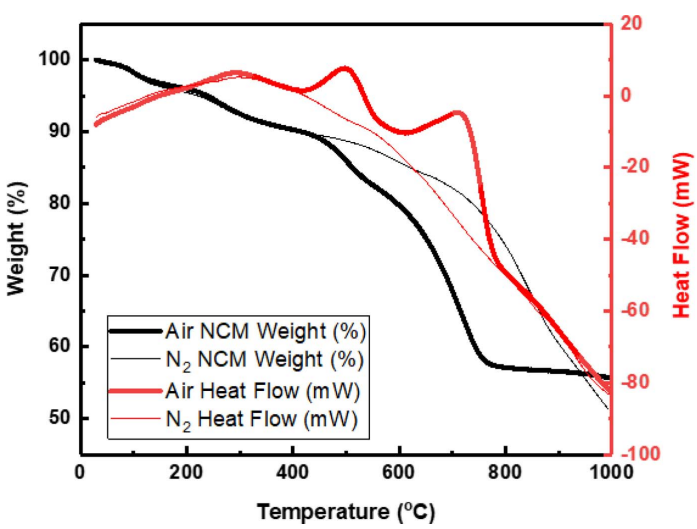

Fig. 3. TG-DSC analysis in Nitrogen and air atmospheres.

소를 포함하는 유기물과 산소가 반응하여 무게 감소가 나타난다. 대기분위기에서는 $750{ }^{\circ} \mathrm{C}$ 까지 무게 감소가 나 타나고 이후 감소가 나타나지 않았다. 이는 대기중의 산 소와 탄소를 포함하는 유기물의 반응으로 제거되었기 때문으로 판단된다. 반면 질소분위기에서 시험 시 $723{ }^{\circ} \mathrm{C}$ 를 기점으로 감소량이 크다. 이는 $\mathrm{Li}_{2} \mathrm{CO}_{3}$ 가 분해 되어 $\mathrm{Li}_{2} \mathrm{O}$ 로 변환되었기 때문으로 판단된다. 또한 대 기분위기에서 시험에 비해 더 감소가 이루어졌는데, 이 는 산화물의 환원으로 결합된 산소가 제거 되었기 때 문이다.

\section{2. 열처리 및 침출 방법}

전기차 셀 내에 탄소는 열처리 시 탄소환원반응으로 산화물을 환원시킨다. 따라서 열처리 분위기와 온도에 따른 환원 및 리튬의 화합물 상이 다르게 나타나고, 리 튬의 침출율에 영향을 미친다.

대기 및 질소 분위기를 위해 튜브형 열처리로 (Taeyoung electric heater Co., Korea)를 사용하였으며, 열처리의 승온속도는 $5{ }^{\circ} \mathrm{C} / \mathrm{min}$ 로 하였으며, 550,700 , $850{ }^{\circ} \mathrm{C}$ 로 1시간 동안 열처리 하였다. 조건 별 열처리 후 분말의 상을 $\mathrm{XRD}$ 로 분석 하여, 온도에 따른 리튬 화합물을 분석하였다. 열처리 된 분말은 $25 \sim 80{ }^{\circ} \mathrm{C}$ 의 D.I water으로 고액비 $1: 5,1: 10,1: 15,1: 20$, 교반속도 $200 \mathrm{RPM}$ 침출을 진행하였다. 침출 후 리튬 및 타 금 속의 침출 정도를 ICP-OES를 사용하여 분석하여 리튬 의 침출율을 분석하였다. 추가적으로 침출된 용액으로 부터 탄산리튬의 회수 가능성을 알아보기 위해 고액분 리 후 증발농축법을 사용하여 XRD 분석을 실시하였다. 


\section{3. 실험결과 및 고찰}

\section{1. 열처리 분위기 및 온도 영향}

폐LIB로부터 선택적 리튬 우선침출에 초점을 맞추며, Fig. 4의 개략도 공정에 따라 열처리 및 침출 실험을 진행하였다. D.I water 내에서 리튬의 침출이 발생하기 위해서는 $\mathrm{LiNi}_{\mathrm{x}} \mathrm{Co}_{\mathrm{y}} \mathrm{Mn}_{\mathrm{z}} \mathrm{O}_{2}$ 와 $\mathrm{LiCoO}_{2}$ 의 환원을 통한 상 분리가 필수적이다. 리튬을 포함하는 산화물은 고온에 서 탄소와 반응하여 $\mathrm{Li}_{2} \mathrm{CO}_{3}$ 을 형성하며 D.I water에서 침출이 가능하다. 열처리 온도에 따라 리튬의 상이 변 화되기 때문에 열처리 후 환원결과는 XRD로 분석하였 으며, Fig. $5 \sim 6$ 와 같다. 대기분위기에서 열처리시 Fig. 5(a)에 나타낸 것과 같이 $550{ }^{\circ} \mathrm{C}$ 에서는 리튬을 포 함하는 산화물의 환원이 원활하게 발생하지 않은 것을 알 수 있었고, $700{ }^{\circ} \mathrm{C}$ 에서 $\mathrm{Li}_{2} \mathrm{CO}_{3}$ 의 발생을 확인할 수

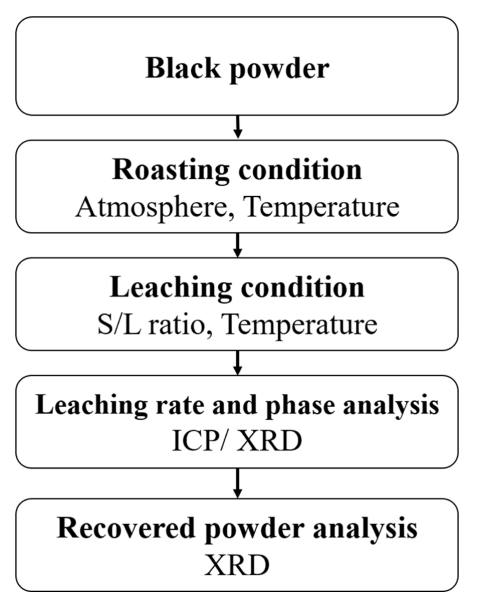

Fig. 4. Selective Lithium Leaching Experimental Process.

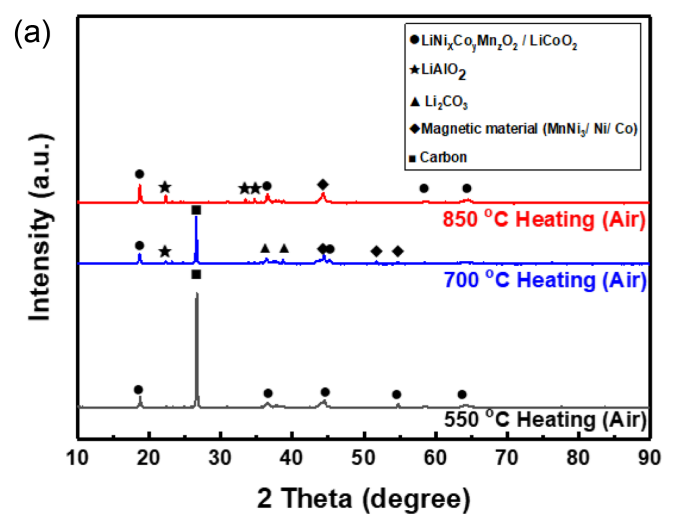

Fig. 5. (a) XRD analysis and (b) lithium leaching ratio in D.I water after roasting in air atmosphere.
있었다. 하지만 대기분위기 $850{ }^{\circ} \mathrm{C}$ 열처리 시 탄소peak 가 없는 것으로 보아 대기중의 산소와 모두 반응하여 추가적인 환원반응이 발생하지 않는 것을 알 수 있다. 이러한 이유로 환원발생이 발생하지 않으며, $\mathrm{Li}_{2} \mathrm{CO}_{3}$ 의 peak가 사라지고 $\mathrm{LiNi}_{\mathrm{x}} \mathrm{Co}_{\mathrm{y}} \mathrm{Mn}_{\mathrm{z}} \mathrm{O}_{2}$ 와 $\mathrm{LiCoO}_{2}$ peak가 다 시 발생하는 것을 확인하였다. 대기분위기 열처리에 따 른 침출 결과를 알고자 ICP 분석을 실시하였으며, Fig. $5(\mathrm{~b})$ 와 같이 나타났다. 리튬이 가장 침출하기 좋은 상태 는 $\mathrm{Li}_{2} \mathrm{CO}_{3}$ 로 존재하는 $700{ }^{\circ} \mathrm{C}$ 에서 침출율이 가장 높았 으며, $850{ }^{\circ} \mathrm{C}$ 온도 열처리 후 침출하였을 경우 리튬 침 출율이 $5 \%$ 이하로 낮았다. Fig. 6(a)의 $\mathrm{NCM}, \mathrm{LCO}$ 및 $\mathrm{LiAlO}_{2}$ peak로 보아 $850{ }^{\circ} \mathrm{C}$ 열처리로 인해 발생한 반응물이 리튬침출에 영향을 미쳤다는 것을 알 수 있었 다. $\mathrm{NCM}, \mathrm{LCO}$ 및 $\mathrm{LiAlO}_{2}$ 의 경우 대기중의 산소와 폐 전기차 분말 내에 탄소가 반응하여 소모가 된 이후, $\mathrm{Li}_{2} \mathrm{O}$ 가 $\mathrm{Co}, \mathrm{Ni} \mathrm{Mn}$ 등의 산화물이 반응했기 때문으로 판단된다.

질소분위기에서 열처리 시 Fig. 6(a)에 나타낸 것과 같이 리튬을 포함하는 산화물의 환원으로 $\mathrm{Co}, \mathrm{Ni}$ 등의 peak가 나타났다. $700,850{ }^{\circ} \mathrm{C}$ 에서 $\mathrm{Li}_{2} \mathrm{CO}_{3}$ 의 peak가 나타났으나 $850{ }^{\circ} \mathrm{C}$ 에서는 $\mathrm{LiAlO}_{2}$ 의 peak가 확인 되는 것으로 보아 $\mathrm{Li}_{2} \mathrm{O}$ 와 $\mathrm{Al}_{2} \mathrm{O}_{3}$ 와 반응 한 것을 알 수 있 다. 리튬의 침출율은 Fig. 6(b)에 나타난 것처럼 $700{ }^{\circ} \mathrm{C}$ 에서 높았으며, $850{ }^{\circ} \mathrm{C}$ 에서는 감소하는 것을 알 수 있었다. 대기분위기 중 열처리공정을 진행한 경우와 비교하면 $850{ }^{\circ} \mathrm{C}$ 에서 리튬침출율의 감소가 비교적 적다. 이는 대기중에서 열처리 시 탄소가 대기중의 산소와 반 응으로 소모되고 시료의 환원이 원활하게 이루어 지지 않기 때문이다. 반면에 질소분위기에서 열처리 시 무산 소분위기에서 탄소와 시료의 반응 반응하므로 환원이

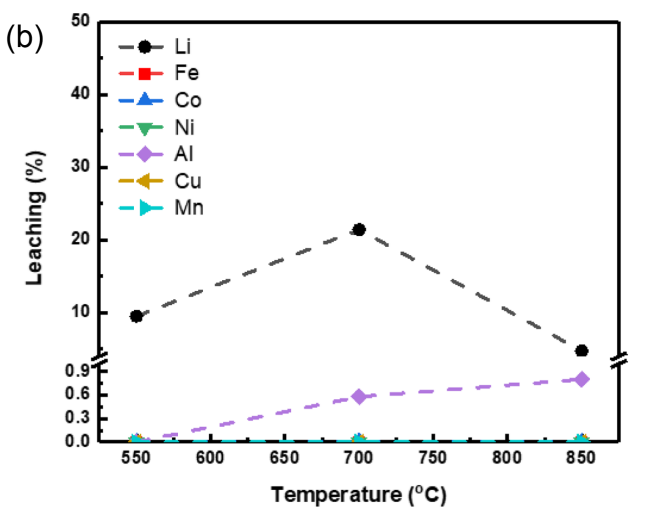



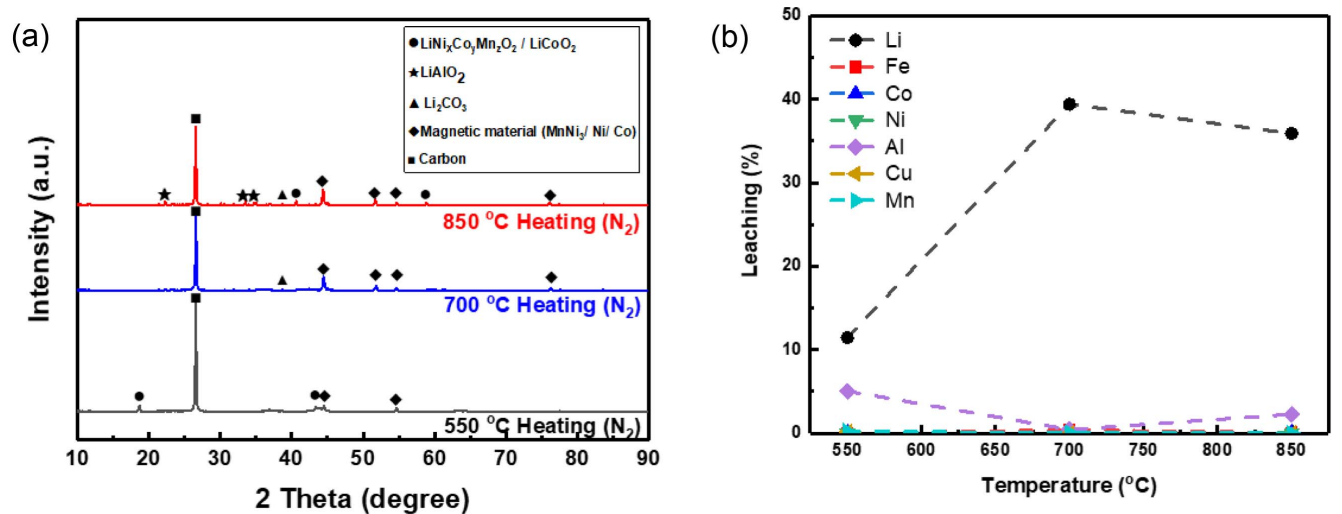

Fig. 6. (a) XRD analysis and (b) lithium leaching ratio in D.I water after roasting in nitrogen atmosphere roasting.
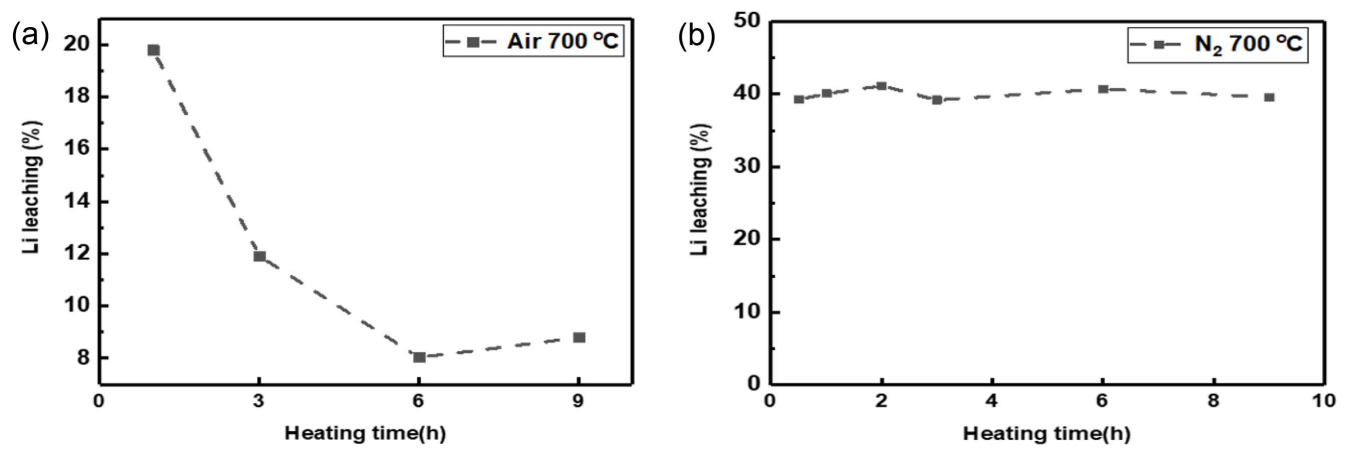

Fig. 7. Lithium leaching ratio with time in (a) atmosphere roasting and (b) nitrogen atmosphere.

원활하게 이루어진다. 따라서 질소분위기에서 열처리 시 리튬 침출율이 우수하다. 하지만 질소분위기에서도 $850^{\circ} \mathrm{C}$ 에서 열처리 시 리튬침출율이 미세하게 감소한다. 이는 Fig. 6(a)에 나타낸 것과 같이 Al과 반응하고, 반 응물은 물에 침출되지 않는다.

$700{ }^{\circ} \mathrm{C}$ 열처리 시간에 따른 침출율을 분석한결과, Fig. 7(a) 처럼 대기분위기 열처리시 시간이 길어짐에 따라 리튬침출율이 낮아지는 반면 질소분위기에서 열처 리시 Fig. 7(b) 처럼 짐출율에 변화가 없었다. 대기분위 기 $700{ }^{\circ} \mathrm{C}$ 열처리 시간에 따른 리튬침출율 감소 원인은 Fig. 8 에 나타난 것과 같이 탄소의 소모 이후 환원되었 던 $\mathrm{Co}, \mathrm{N}$ i등의 금속이 $\mathrm{Li}_{2} \mathrm{CO}_{3}$ 와 반응하여 $\mathrm{LCO}$ 를 형성하기 때문으로 판단된다. 대기분위기 중 열처리 시 탄소의 유무가 리튬을 포함하는 산화물의 환원 및 산화 에 영향 미치는 반면 질소분위기에서는 탄소가 시료 내 에 산소와 반응하므로 큰 영향이 없다.

질소분위기 중 $700{ }^{\circ} \mathrm{C}$ 에서 열처리했을 때 침출율이 가장높았으며, 열처리 시간은 크게 영향이 없었다. 열처

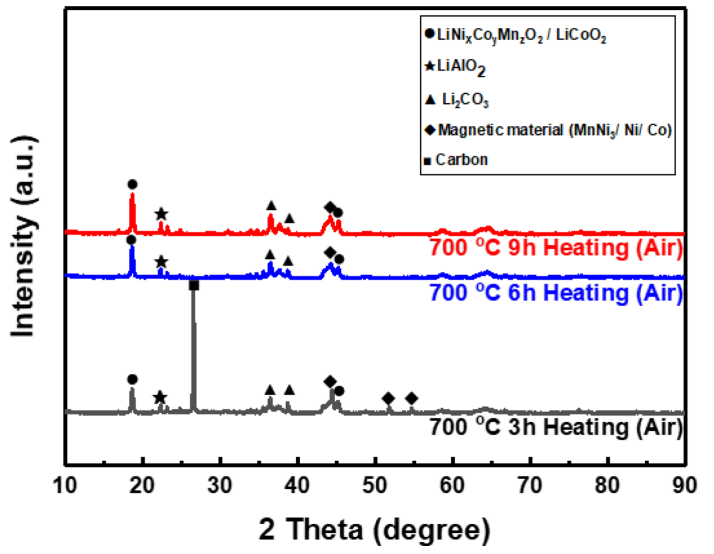

Fig. 8. XRD analysis according to roasting time in air atmosphere of $700{ }^{\circ} \mathrm{C}$.

리 후 상온의 D.I water에서 $1: 10$ 의 고액비로 침출 시 리튬침출율이 약 $40 \%$ 임을 알 수 있었다. 

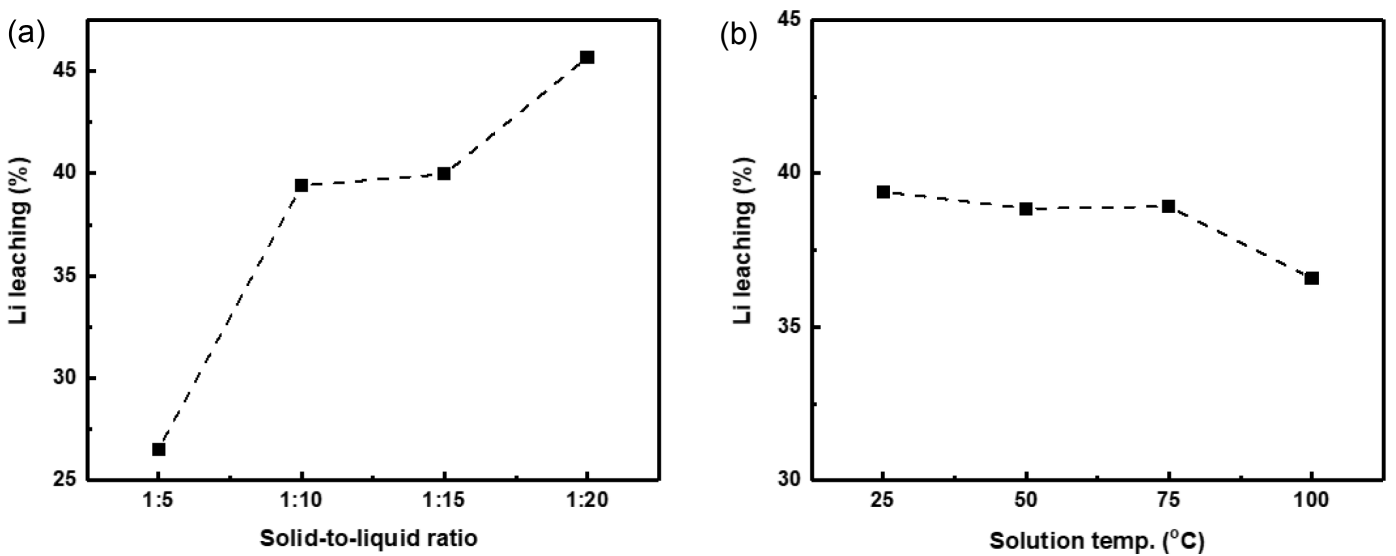

Fig. 9. Lithium leaching ratio by (a) solid-liquid ratio and (b) leaching solution temperature after nitrogen atmosphere of $700{ }^{\circ} \mathrm{C}$.

\section{2. 고액비 영향}

$\mathrm{Li}_{2} \mathrm{CO}_{3}$ 의 효율적인 침출조건을 알기 위해서 질소 분 위기에서 $700{ }^{\circ} \mathrm{C}$ 열처리를 통한 $\mathrm{Li}_{2} \mathrm{CO}_{3}$ 형성 후 침출 고액비에 따른 리튬침출율을 분석한 결과 Fig. 9(a)처럼 같은 결과가 나타났다. 고액비의 증가에 따라 리튬침출 이 증가하는것으로 보아 높은 고액비가 리튬 침출에 유
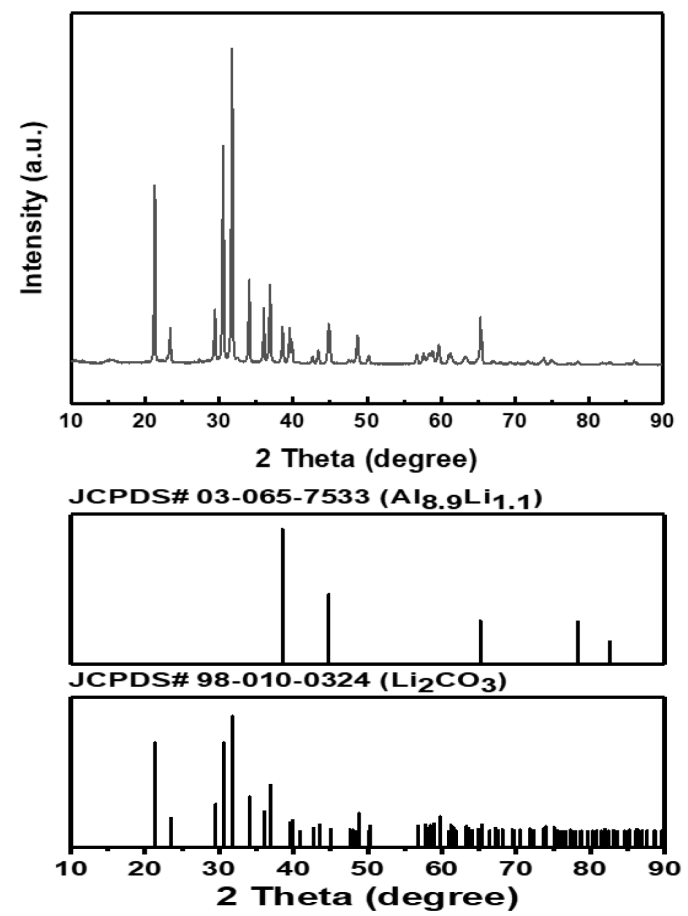

Fig. 10. XRD analysis of evaporative concentration after solid-liquid saparation.
리하나 증발농축을 통한 회수시 효율이 떨어짐을 고려 하여 적정 고액비 선정이 필요하다.

\section{3. 침출온도 영향}

열처리 후 D.I water에서의 침출시 Fig. 9(b)처럼 저 온에서 침출율이 높다. 이는 폐 전기차 셀분말 내에 탄 소로 인해 산화물이 환원하면서 발생한 $\mathrm{CO}, \mathrm{CO}_{2}$ 등의 가스와 환원시 발생한 $\mathrm{Li}_{2} \mathrm{O}$ 와 반응으로 생성된 $\mathrm{Li}_{2} \mathrm{CO}_{3}$ 의 특성 때문이다. $\mathrm{Li}_{2} \mathrm{CO}_{3}$ 의 경우 용해도가 낮으며, 특 성상 침출율 향상을 위해서 저온에서의 침출이 유리하 다. 이러한 특성을 이용하여 저온에서 탄산리튬 침출 후 용액을 가열할 경우 용해도가 낮아지므로 탄산리튬을 회수가 가능할 것으로 판단된다.

\section{4. 회수분말 분석}

탄산리튬의 회수 및 소재화의 가능성을 확인하고자 침출용액의 고액분리 후 증발농축을 실시한 결과, Fig. 10 과 같이 $\mathrm{Li}_{2} \mathrm{CO}_{3}$ 피크를 확인할 수 있었다. 이와 같 이 선택적 리튬 우선침출을 통한 $\mathrm{Li}_{2} \mathrm{CO}_{3}$ 회수가 가능 하나 현재 리튬침출율이 다소 낮으므로 향후 침출율 향 상을 위한 추가적인 연구 진행 예정이다.

\section{4. 결 론}

본 연구에서는 최근 발생량이 급증하고 있는 폐 LIB 내 리튬의 선침출을 위한 연구로 효율적인 리튬 회수 공정을 제안하였고, 열처리 및 침출공정을 수행하여 다 음과 같은 결과를 얻었다.

열처리 분위기(질소, 대기) 및 온도 $\left(550 \sim 850{ }^{\circ} \mathrm{C}\right)$ 에 
따른 상변화 분석을 위한 XRD 분석 및 열처리 조건 별(온도 및 고액비) 침출 후 ICP 분석을 통해 리튬침 출율을 분석하였다.

$\mathrm{XRD}$ 분석결과 질소분위기 $700{ }^{\circ} \mathrm{C}$ 로 열처리 시 $\mathrm{Co}$, $\mathrm{Ni}$ 등의 환원이 잘 발생했으며, 리튬은 $\mathrm{Li}_{2} \mathrm{CO}_{3}$ 로 존재 한다.

질소 분위기 중 $700{ }^{\circ} \mathrm{C}$ 조건에서의 열처리 후 고액 비 $1: 10$ 으로 침출 시 리튬을 약 $40 \%$ 침출 및 회수 가 가능하다.

온도가 낮고 고액비가 클수록 $\mathrm{Li}_{2} \mathrm{CO}_{3}$ 의 침출이 원활 하게 발생하였으며, 1:20 고액비에서 약 $45 \%$ 의 리튬 침출이 발생하였다.

침출된 용액을 고액분리 하여 증발농축하여 $\mathrm{Li}_{2} \mathrm{CO}_{3}$ 의 회수가 가능함을 $\mathrm{XRD}$ 를 통해 확인하였다.

본 연구에서는 열처리 및 침출 조건에 따른 선택적 리튬침출에 적합한 조건을 찾고자 하였으며, 위와 같은 결과를 얻었다. 효율적인 선택적 리튬 우선침출 및 회 수를 위해서 온도 세분화 및 열처리 시간, 불순물 등에 따른 리튬침출율에 대한 추가적인 연구가 진행될 예정 이다.

\section{감사의 글}

본 연구는 2019년도 산업통상자원부의 재원으로 한 국에너지기술평가원(KETEP)의 지원을 받아 수행한 연 구 과제(No. 20185210100050)이며, 이에 감사드립니다.

\section{정 연 재}

• 현재 한국생산기술연구원 표면처리그룹 학생 연구원

- 현재 한양대학교 재료화학공학과 박사과정

- 당 학회지 제 26 권 6 호 참조

\section{References}

1. Martin, Rentsch and Gunther 2017 : Lithium market research-global supply, future demand and price development, Energy Storage Materials, (6), pp.171-179.

2. Bunsen, T., Cazzola, Gorner, et al., 2018 : Global EV Outlook 2018: Towards cross-modal electrification., International Energy Agency.

3. Kim, Yanghwa, et al., 2019 : Electric Vehicle Market and Battery Related Technology Research Trends, Transactions of the Korean hydrogen and new energy society, 30(4), pp.362-368.

4. Zhang, Xihua, et al., 2013 : An overview on the processes and technologies for recycling cathodic active materials from spent lithium-ion batteries, Journal of Material Cycles and Waste Management, 15(4), pp.420-430.

5. Paulino, et al., 2008 : Recovery of valuable elements from spent Li-batteries, Journal of Hazardous Materials, 150(3), pp.843-849.

6. Miller, James F., and Urs Muntwyler, 2016 : International Cooperation on Public Policies and Strategies for Hybrid \& Electric Vehicles under the International Energy Agency, World Electric Vehicle Journal, 8(4), pp.842-845.

7. Ballon and Massie Santos, 2010 : Electrovaya, Tata Motors to make electric Indica, cleantech. com. Cleantech Group. Retrieved, 11.

8. Meshram, Pratima, B. D. Pandey, and T. R. Mankhand, 2014 : Extraction of lithium from primary and secondary sources by pre-treatment, leaching and separation: A comprehensive review, Hydrometallurgy, 150, pp.192-208.

9. Lee, Churl Kyoung, and Kang-In Rhee, 2002 : Preparation of $\mathrm{LiCoO}_{2}$ from spent lithium-ion batteries, Journal of Power Sources, 109(1), pp.17-21.

\section{손 성 호}

\author{
• 현재 한국생산기술연구원 표면처리그룹 수석 \\ 연구원
}

- 당 학회지 제 25 권 4 호 참조 

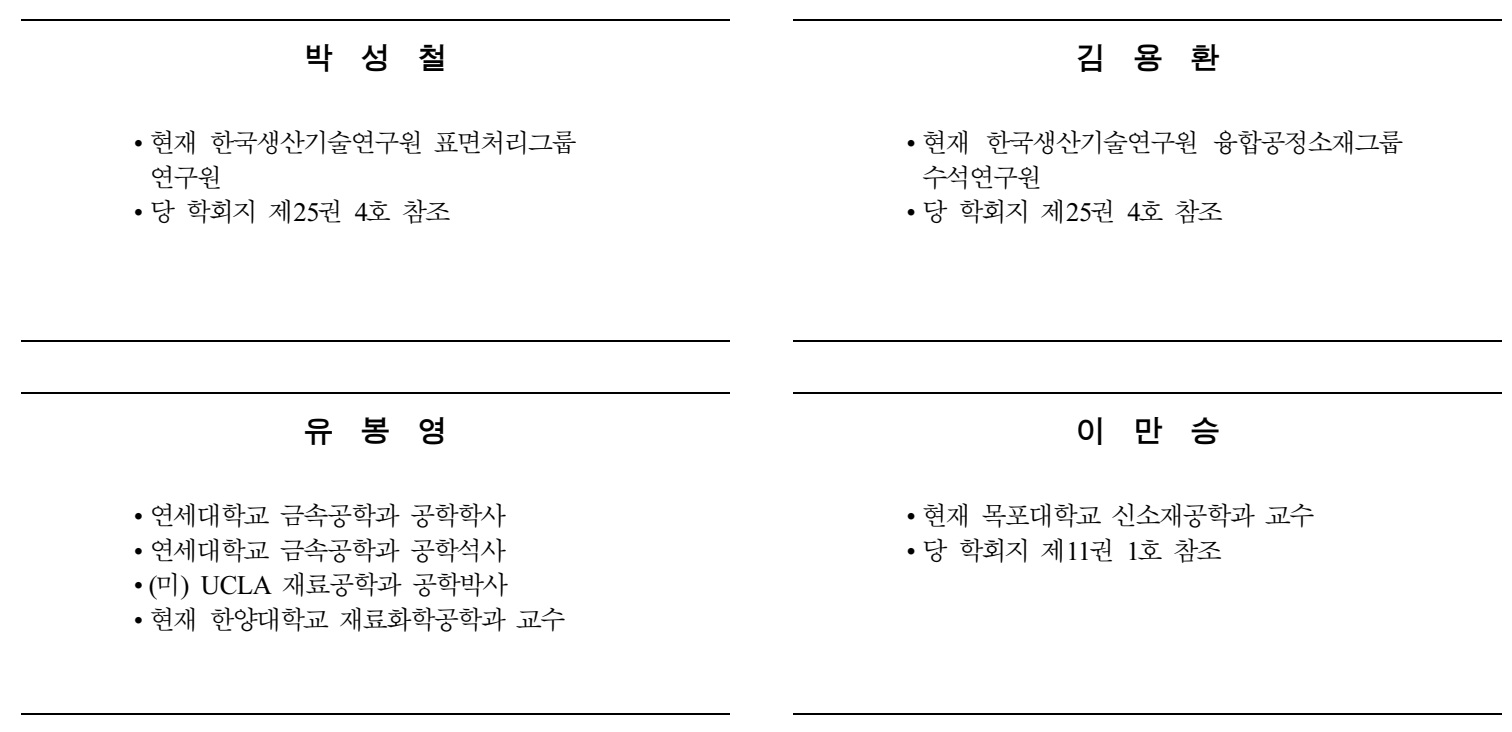

\section{學會誌 投稿 安內}

\begin{tabular}{|c|c|}
\hline 種 類 & 容 \\
\hline 論說 & 提案, 意見, 批判, 時評 \\
\hline 展望, 解說 & 現況과 將來의 견해, 研究 技術의 綜合解說, Review \\
\hline 技術報告 & 實際的인 試驗, 調査의 報告 \\
\hline 技術, 行政情報 & 價值있는 技術, 行政情報를 간결히 解說하고, comment를 붙인다. \\
\hline 見 聞 記 & 國際會義年 報告, 國內外의 研究 幾關의 見學記 등 \\
\hline 書 評 & \\
\hline 談 話 室 & 會員相互의 情報交換, 會員 自由스러운 말, 隋霜 등 \\
\hline Group 紹介 & 企業, 研究幾關, 大學 등의 紹介 \\
\hline 研究論文 & $\begin{array}{l}\text { Original 硎究論文으로 本 學會의 會誌에 揭戴하는 것이 } \\
\text { 薑當하다고 보여지는 것 }\end{array}$ \\
\hline
\end{tabular}

수시로 원고를 접수하오니 많은 투고를 바랍니다. 